\title{
Levels of essential and non-essential metals in edible mushrooms cultivated in Haramaya, Ethiopia
}

\author{
Medhanye Gebrelibanos ${ }^{1 *}$, Negussie Megersa ${ }^{2}$ and Abi M. Taddesse ${ }^{3}$
}

\begin{abstract}
Background: Fruiting bodies of two oyster mushroom (Pleurotus ostreatus and Pleurotus florida) species and their respective substrate samples cultivated and collected from the Mushroom Research, Production and Training Laboratory of the Haramaya University, Ethiopia, were analyzed for essential and non-essential metals, viz., Cu, Fe, $\mathrm{Zn}, \mathrm{Mn}, \mathrm{Cd}$ and $\mathrm{Pb}$ contents by flame atomic absorption spectrometry after digestion employing dry, wet and microwave digestion techniques. Concentrations of the analyzed metals were expressed on a dry weight basis (mg/kg).

Results: The mean metal concentration ( $\mathrm{mg} / \mathrm{kg}$ in dry weight) in the mushroom and respective substrate samples, respectively; for Pleurotus ostreatus were: Cu $(51.19,48.97)$, Fe $(220.87,299.51)$, Zn $(89.68,62.55)$ and Mn $(47.55,58.32)$. The mean metal concentration ( $\mathrm{mg} / \mathrm{kg}$ in dry weight) in mushroom and the respective substrate samples, respectively, for Pleurotus florida were: Cu (53.56, 51.87), Fe (243.92, 265.23), Zn (95.26, 64.25) and Mn (41.29, 62.55). However, Cd and $\mathrm{Pb}$ was not detected in both mushroom and substrate samples. The bio-accumulation factor of the heavy metals was calculated and a highest accumulation of $\mathrm{Cu}$ and $\mathrm{Zn}$ from substrate was observed for all the analyzed mushrooms samples. The observed results were also compared with the reported results.

Conclusions: In this study, the highest concentrations of $\mathrm{Cu}, \mathrm{Fe}, \mathrm{Zn}$ and $\mathrm{Mn}$ were confirmed. These elements generally are essential for humans, and may not possibly cause health problems even if mushrooms are consumed regularly. Furthermore, the quantities of the metals found in the samples were within the limits recommended by international organizations like the WHO/FAO Expert Committee on Food Additives. On the other hand, the amounts of $\mathrm{Cd}$ and $\mathrm{Pb}$ were found to be very low. These elements are toxic to humans, especially at higher doses; however, the concentrations of these non-essential metals were below detectable limit.
\end{abstract}

Keywords: Edible mushrooms, Substrate, Fruiting body, Sample digestion, Essential metals, Non-essential metals, BCF

\section{Background}

Mushrooms are fungi fruit-bodies that spontaneously grow in forests and farmlands in large quantities after the rainy seasons. The natural substrates of the mushrooms include logs of woods, decomposed agro- and animal wastes, and soil where nutrients are available through external digestion and absorption by the mycelium. There are edible and poisonous mushrooms and both categories possess nutritional and medicinal values (Okwulehie and Ogoke 2013). The consumption of wild

\footnotetext{
* Correspondence: meda387@gmail.com

${ }^{1}$ Department of Industrial Chemistry, School of Biological and Chemical Sciences and Technology, Addis Ababa Science and Technology University, P. O. Box 16417, Addis Ababa, Ethiopia

Full list of author information is available at the end of the article
}

edible mushrooms is increasing from time to time, in the developed world, mainly due to their contents of proteins as well as trace minerals (Agrahar-Murugkar and Subbuakshmi 2005). Besides, wild growing and cultivated mushrooms are considered popular food in several countries, mainly in Europe and Asia, because of their favorite delicacy (Kalac 2010; Zhu et al. 2011). Furthermore, mushrooms have been reported as therapeutic foods; useful in preventing from diseases and exhibiting varied biological properties such as antibacterial, antimutagenic, antitumoral and antiviral activities (Garcia-Lafuente et al. 2011; Schillaci et al. 2013). These functional characteristics are mainly because of their chemical composition (Manzi et al. 2001). In this regard, fruiting bodies of the mushrooms, on a dry weight basis, contain about $39.9 \%$

\section{实 Springer}

(c) 2016 Gebrelibanos et al. Open Access This article is distributed under the terms of the Creative Commons Attribution 4.0 International License (http://creativecommons.org/licenses/by/4.0/), which permits unrestricted use, distribution, and reproduction in any medium, provided you give appropriate credit to the original author(s) and the source, provide a link to the Creative Commons license, and indicate if changes were made. 
carbohydrate, $17.5 \%$ protein and $2.9 \%$ fats, the rest being minerals (Demirbas 2001).

Living organisms require varying amounts of "heavy metals" including iron, copper, manganese and zinc, that are essential and required by humans as they play important roles in biological systems, though excessive levels may result in damaging effects to the organism. Other heavy metals such as cadmium and lead are toxic and non-essential and their accumulation over time in human bodies could cause serious illnesses (Obodai et al. 2014). Accurate and adequate food composition data are invaluable for estimating the adequacy of intakes of essential metals and assessing exposure risks from intake of toxic non-essential metals (Soylak et al. 2005). For example, the bioavailability of iron in mushrooms is considerably high and human body can absorb up to $90 \%$ of the available form (Kalac and Svoboda 2000). The recommended dietary allowances (RDA) are $0.9,8.0-18.0,8.0-11.0$ and $1.8-2.3 \mathrm{mg}$ per day for $\mathrm{Cu}$, $\mathrm{Fe}, \mathrm{Zn}$ and $\mathrm{Mn}$, respectively. This level is sufficient to meet the nutrient requirement of nearly all (97 to $98 \%$ ) healthy individuals, in a particular life stage and gender group (Ross et al. 2011).

Metal concentrations in mushrooms are considerably higher than those in agricultural crops, vegetables and fruits. This suggests that mushrooms possess effective mechanisms that enable them to readily take up some metals from the ecosystem compared to the green plants growing in similar localities (Svoboda et al. 2000). Reported study has indicated that concentrations of metals in macrofungi depend on the physiology of the species and particularly on the ecosystem pattern (Sesli et al. 2008). In addition, accumulation of metals in the mushrooms was found to be species metabolism-dependent and also strongly affected by the chemical composition of the substrate from which the mushrooms get their nutrients (Radulescu et al. 2010). As the macrofungi are integral part of the forest ecosystems, sometimes the substrate-to-mycelium transfer of metals depend on the relationship between mycelium and symbiotic plant species affecting element absorption and translocation (Yoshida and Muramatsu 1997).

Furthermore, accumulation of heavy metals in macrofungi has been noted to be affected by environmental and fungal factors. Environmental factors, such as organic matter contents, $\mathrm{pH}$, metal concentrations in soil or substrate and fungal factors, such as species of mushroom, morphological part of fruiting body, development stages, age of mycelium and biochemical composition are known to affect metal accumulation in macrofungi (Kalac and Svoboda 2000; Isiloglu et al. 2001).

The importance of mushrooms in the ecosystem can be described by their ability to biodegrade the substrate and therefore use the wastes of agricultural production
(Sarikurkcu et al. 2011). In several countries, there is a well-established consumer acceptance of cultivated mushrooms, such as Agaricus bisporus, Pleurotus species, Lentinus edodes and others (Diez and Alvarez 2001). Kues and Liu (2000) reported that the Pleurotus species are well known edible mushrooms in different parts of the world while other workers stated that oyster mushroom (Pleurotus florida) cultivation is gaining popularity due to low cost technology and easy availability of the various substrates for its cultivation (Shukla and Biswas (2000)). Pleurotus species, as primary wood rot fungi, have the capacity to colonize different types of agricultural wastes as substrates (Zadrazil and Dube 1992). Additionally, mushrooms are commonly cultivated on single substrates, commonly wheat or paddy straw (Ragunathan and Swaminathan 2003).

The mushroom cultivation practices and consumption in Ethiopia is still very low compared to other countries in Europe and Asia. However, mushroom consumption is increasing due to the intense advertising of its numerous benefits. Besides their nutritional values, mushrooms possess medicinal proprieties in prevention of some diseases, such as hypertension and cancer (Manzi et al. 2001). Although there were several studies carried out in several countries on metals concentrations in the fruiting bodies of edible wild grown and cultivated mushrooms (Tuzen et al. 2007; Sesli et al. 2008; Baslar et al. 2009; Radulescu et al. 2010; Sarikurkcu et al. 2011; Zhu et al. 2011; Sen et al. 2012; Okwulehie and Ogoke 2013; Obodai et al. 2014; Dulay et al. 2015), however, such studies are still very scarce in Ethiopia. Therefore, initiation of such study for better understanding of the types of mushrooms cultivated and consumed in the country in relation to the essential and non- essential metals is very much demanding and timely.

Since heavy metals could enter the food chain, for example, as a result of uptake by edible mushrooms, it is necessary to determine the levels of essential and nonessential metals and report possible contamination level that could be the cause for health hazard. However, there have been no such reports, on the essential and non-essential metal levels in oyster mushroom samples cultivated in Ethiopia. In the light of the above, the elemental contents of six essential and non-essential metals $(\mathrm{Cu}, \mathrm{Zn}, \mathrm{Fe}, \mathrm{Mn}, \mathrm{Cd}$, and $\mathrm{Pb})$ in two different edible oyster mushroom species cultivated in Haramaya, Ethiopia, on wheat straw substrate were investigated.

\section{Methods}

\section{Description of the sampling area}

Cultivation of oyster mushrooms (Pleurotus spp.) was carried out at the Mushroom Research, Production and Training Laboratory of the Haramaya University, Ethiopia; located at $42^{\circ} 3^{\prime} \mathrm{E}$ longitude, $9^{\circ} 26^{\prime} \mathrm{N}$ latitude and 
altitude of $1980 \mathrm{~m}$ above the sea level (AUA 1996). Temperature of the experimental room was found to vary from 12.96 to $25.72{ }^{\circ} \mathrm{C}$, while the relative humidity ranging from 57.67 to $91.93 \%$.

\section{Oyster (Pleurotus spp.) mushroom cultivation Source of mushroom strain}

Pure cultures of two edible oyster mushroom species; namely; Pleurotus ostreatus and Pleurotus florida, were obtained from the cultivation center. The cultures were initially multiplied on sterilized potato dextrose agar (PDA) medium to get enough stock culture of the pure species needed to prepare the required quantity of spawn (Sara 2007). Stock culture was grown by transferring the PDA cultures into the flasks containing maize seeds as described below (subsection Spawn preparation).

\section{Spawn preparation}

Preparation and sterilization of spawn substrate Mother spawn was prepared according to the procedure described by Singh and Chaube (1995). Accordingly, $9 \mathrm{~kg}$ maize seeds were boiled in $15 \mathrm{~L}$ water for $15 \mathrm{~min}$ and allowed to remain soaked in the hot water for another $25 \mathrm{~min}$. The water was then drained off and the maize seeds were kept in a sieve overnight to dry. The next day, 120 g calcium sulfate and 30 g calcium carbonate were mixed with each boiled maize seeds, in order to maintain the $\mathrm{pH}$ close to neutrality and reduced adhesion of the maize seeds (Smith and Margarel 1995). Thereafter, the supplemented maize seeds were filled in half or one liter sterilizable bottles (225 or $450 \mathrm{~g} / \mathrm{bottle}$ ), plugged with non-absorbent cotton and sterilized in autoclave at $121{ }^{\circ} \mathrm{C}$ for half an hour. Subsequently, the bottles were cooled and then inoculated with pure stock culture by taking a piece of agar with mycelium. At this stage, the culture and the prepared maize seeds were thoroughly mixed in order to distribute the mycelium uniformly which were incubated at $25{ }^{\circ} \mathrm{C}$. Finally, the maize seeds were fully covered with mycelium, and then the bottles were used as a mother spawn.

Inoculation of the spawn substrate Inoculation of spawn substrate was performed by transferring small amount of agar with mycelium, from stock culture, to the flask containing the substrate under aseptic condition over the flame. This was followed by thoroughly mixing the mycelium with the maize seeds in the flasks and the flask was then incubated at $25^{\circ} \mathrm{C}$, in an incubator. After seven days of incubation, the content of the flasks was shaken to facilitate uniform mixing of the mycelium over the maize seeds. The flask was then incubated until all the maize seeds fully covered with mycelium in about 15 days (Sara 2007).

\section{Substrate preparation and cultivation}

The substrate, wheat straw, was collected from the farmlands of the mushroom research center of the Haramaya University. It was then undergone the following experimental steps: initially the wheat straws were chopped to approximately $8-12 \mathrm{~cm}$ size pieces and filled in the gunny bags, and then soaked in $2 \%$ aqueous formalin solution for about $18 \mathrm{~h}$. The bags were taken out of the solution and allowed to drain the excess solution for $4-6$ h. The soaked pieces of the wheat straw materials were then checked for remaining excess solution by pressing between the palms. When there is no dripping of solution, the chopped wheat straw material was considered 'ready for spawning' (Sara 2007). The wet substrate materials were then spread over a clean alcohol swabbed polyethylene sheet and inoculated with the spawn; prepared at the rate of $3 \%$ on wet basis. The resulting spawn was thoroughly mixed with the substrate and then filled into the plastic bags (about $2 \mathrm{~kg}$ per bag). Following spawning, the bags were kept about $15 \mathrm{~cm}$ apart in a crop room; with the temperature maintained around $25-30{ }^{\circ} \mathrm{C}$ and humidity ranging from 70 to $90 \%$. The temperature and humidity of the cropping room were controlled to the required ranges using a heater and spraying water to the walls and floors of the room. During cropping or harvesting period, the bags were sprinkled with water twice a day (Sara 2007). Finally, after cultivation period of 25 35 days, the fully matured mushroom species, grown on the substrate (wheat straw), were harvested and collected for further treatment. This experiment was performed in triplicate (Fig. 1).

\section{Sample collection and preparation}

For each fruiting body of the mushrooms and their respective substrates, a total of three samples were collected from the cultivation center. The samples were collected during the months of December 2014 and January 2015.

Fruiting bodies of the mushroom samples collected from the center were thoroughly cleaned, cut and oven dried at $60{ }^{\circ} \mathrm{C}$ for $4-6 \mathrm{~h}$. The resulting dried samples were then homogenized using agate homogenizer and stored in pre-cleaned polyethylene bottles for subsequent analysis. The substrate samples, on the other hand, were collected from the surface $(0-15 \mathrm{~cm}$ in depth), where the mushroom samples were grown. They were oven dried at $70{ }^{\circ} \mathrm{C}$ until the entire moisture contained within the sample was removed. After drying, the substrate samples have been homogenized to a fine powder and stored in a pre-cleaned polyethylene bottles for subsequent analysis.

\section{Digestion procedures \\ Dry ashing}

Dried mushroom and substrate samples $(0.5 \mathrm{~g})$ were first placed onto a porcelain crucible. The furnace temperature 

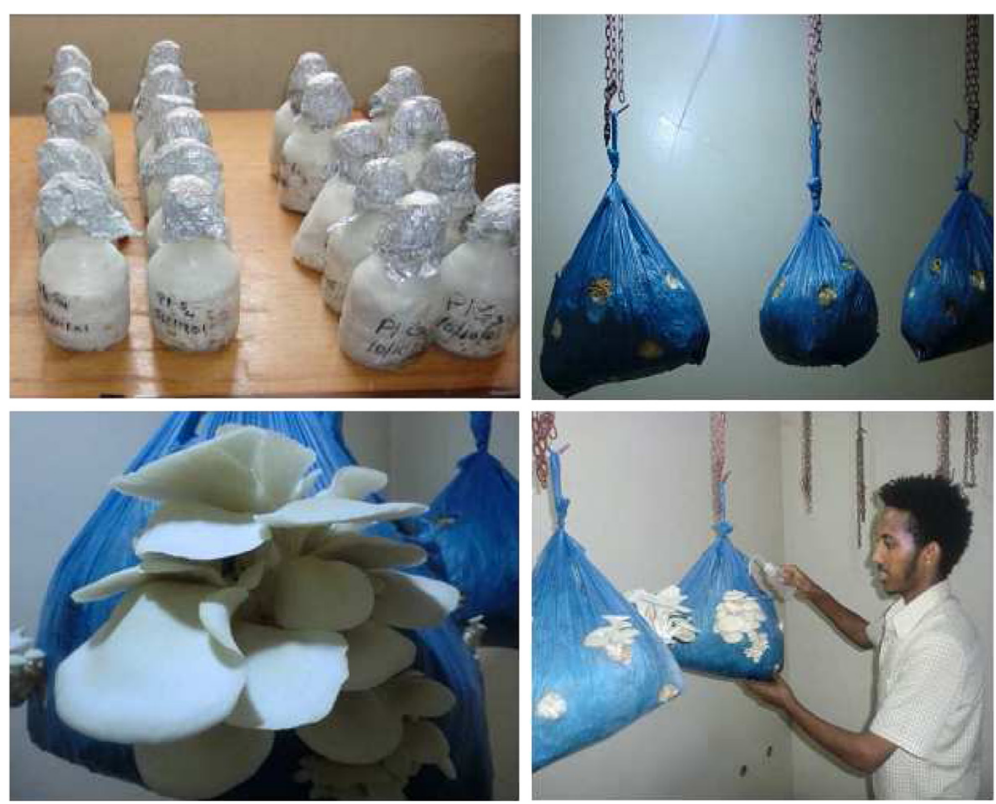

Fig. 1 Spawn and substrate preparation, and mushroom cultivation

was slowly increased from room temperature to 450 and $500{ }^{\circ} \mathrm{C}$ for the mushroom and substrate samples, respectively, in $1 \mathrm{~h}$. Both samples were ashed for about $4 \mathrm{~h}$ until a white or grey ash residue was obtained. The residues were then dissolved in $1 \mathrm{~mL} \mathrm{HNO}$ and $2 \mathrm{~mL} \mathrm{HNO}_{3}$ for mushroom and substrate samples, respectively, and the resulting solutions were transferred to a $50 \mathrm{~mL}$ volumetric flask and made up to a volume with deionized water. Preparation of the blank control, in the absence of analytes, was also carried out in a similar manner.

\section{Wet digestion}

Wet digestion of the mushroom and substrate samples, $0.5 \mathrm{~g}$ each, was performed separately in a $100 \mathrm{~mL}$ beaker, inside the fume hood. The optimum oxi-acid mixture ratio for mushroom digestion was 2:1:1 $(v / v / v)\left(\mathrm{HNO}_{3}: \mathrm{H}_{2} \mathrm{SO}_{4}: \mathrm{H}_{2} \mathrm{O}_{2}\right)$, in a total volume of $12 \mathrm{~mL}$, for $3 \mathrm{~h}$ at $150{ }^{\circ} \mathrm{C}$. On the other hand, for the substrate samples the optimum digestion conditions were found to be $3 \mathrm{~mL} \mathrm{HNO}_{3}$ and $9 \mathrm{~mL} \mathrm{HCl} \mathrm{(aqua} \mathrm{regia)} \mathrm{and}$ a digestion time of $1 \mathrm{~h}$ at $100{ }^{\circ} \mathrm{C}$. Then, the clear solutions for both samples were made up to the final volume of $50 \mathrm{~mL}$ with deionized water. Digestion of the blank control, in the absence of analytes, was also carried out in a similar manner.

\section{Microwave digestion}

Accurately weighed, $0.5 \mathrm{~g}$ of both the mushroom and substrate samples were separately digested, each for 2 min. Digestion of the mushroom samples was performed in the acid mixture composed of $6 \mathrm{~mL}$ of $\mathrm{HNO}_{3}$, $3 \mathrm{~mL} \mathrm{H}_{2} \mathrm{SO}_{4}$ and $3 \mathrm{~mL}$ of $\mathrm{H}_{2} \mathrm{O}_{2}$ in a power of $250 \mathrm{~W}$.
Similarly, for the substrate samples, aqueous acid mixture composed of $6 \mathrm{~mL} \mathrm{HCl}$ and $3 \mathrm{~mL} \mathrm{HNO}_{3}$, in $200 \mathrm{~W}$ power of microwave digestion system. Finally, the resulting clear solutions were diluted to the final volume of $50 \mathrm{~mL}$ with deionized water. Digestion of the blank control, in the absence of analytes, was also carried out in a similar manner.

\section{Evaluation of the method performance and validation of the analytical method}

Standard solutions for calibration were prepared, at five points, from $10 \mathrm{mg} / \mathrm{L}$ intermediate solutions of the respective metals. The instrument was calibrated using a series of working standards. Based on the results obtained from this experimental procedure, concentrations of the various metals in the digests and the corresponding correlation coefficients were determined. The precision of the results were also evaluated based on the standard deviation of the results of triplicate samples $(n=3)$, analyzed under the same conditions.

Limit of detection of the analytical method, LOD, is the lowest analyte concentration that can be detected from the statistical fluctuations of the blank, usually corresponds to the signal that is three times the standard deviation of the blank (LOD $=3^{*} S_{\mathrm{b}}$, where $\mathrm{S}_{\mathrm{b}}$ is the standard deviation (SD) of the blanks) (Miller and Miller 2010). LOD for each element was determined from the standard deviations and calculated based on twelve blank measurements. To this end, twelve blank samples were digested following the same procedures used for the samples and each of the blank samples was analyzed for the metal concentrations, i.e., $\mathrm{Cu}, \mathrm{Fe}, \mathrm{Zn}, \mathrm{Mn}, \mathrm{Cd}$ and $\mathrm{Pb}$. 
The limit of quantification, LOQ, is described as the lowest concentration level at which the measured values could be determined quantitatively and most often defined as 10 times the signal/noise ratio. In this study, LOQ was obtained from triplicate analyses of the blanks, which were digested following the same procedures, both for the mushroom and substrate samples. The LOQ was then calculated using the relation; $\mathrm{LOQ}=10^{*} \mathrm{~S}_{\mathrm{b}}, n=3$, (Miller and Miller 2010).

Similarly, the percent recovery (\%R) was determined by spiking the samples with a standard solution of $100 \mathrm{mg} / \mathrm{L}$ of the analyte metals. From these solutions based upon the amount that makes the concentration of the final solutions to $0.25 \mathrm{mg} / \mathrm{L}(\mathrm{Cu}), 1.50 \mathrm{mg} / \mathrm{L}(\mathrm{Fe})$, $0.10 \mathrm{mg} / \mathrm{L}(\mathrm{Zn})$ and $1.00 \mathrm{mg} / \mathrm{L}(\mathrm{Mn})$ were added to $0.5 \mathrm{~g}$ of both mushroom and the respective substrate samples. Then, the contents were digested following the developed digestion procedures for all the samples. The digested spiked samples were finally analyzed for their respective metal contents. For both mushroom and substrate samples, triplicate digestions were performed and from the recovered quantity of each analyte, percent recoveries were calculated using the equation given below:

$\%$ Recovery $=\frac{\text { Amount After Spike }- \text { Amount Before Spike }}{\text { Amount Added }} \times 100$

\section{Statistical analysis}

All experimental results were presented as means $\pm \mathrm{SD}$ of three parallel measurements. The one way ANOVA and Fisher's least significant difference (LSD) was calculated using Microsoft Excel. Significant difference between treatment means was evaluated using analysis of variance (ANOVA) and for comparison of the means of the treatments, the LSD test was used at $p<0.05$ significance level (Miller and Miller 2010).

\section{Results and discussion}

\section{Evaluation of the analytical method}

Calibration graphs for the six metallic elements, considered in this study, were constructed from the standard solutions at five points, ranging in concentration from 0.5 to $10 \mathrm{mg} / \mathrm{L}$. All the elements exhibited linear relationships of the instrumental response and the solutions containing the metals with insignificant intercepts and correlation coefficients of 0.997 or better.

Observed detection and quantification limits for the metals under the study (in $\mathrm{mg} / \mathrm{kg}$ ) are given in Table 1 . It has also been noted that the method detection limit for each element is above the instrument detection limit, for all the metals under analysis, determinations of which were carried out on dry weight basis.
Precision is the most often quoted term to express the extent of errors in the given analytical results. In this regard, the major concern is critical evaluation of the agreement between the measured values of the set of results for the same quantity (Miller and Miller, 2010). It is usually expressed by the relative standard deviation. In this study, the relative standard deviation determined for each target analyte was found to be less than $10 \%$, Table 2, which indicates the acceptable variability of the analytical results (Eurachem/CITAC 2003; EC 2010).

\section{Percent recovery of the analytical method}

Percent recovery analysis is used for method validation which is the process used for evaluating whether the analytical method is acceptable or not for its intended purpose. Due to the absence of the certified reference materials both for mushroom and substrate samples in our laboratory, validity of the optimized digestion procedures was assured by spiking the samples with the standard solution of known concentration of the analyte metals. As has also been shown in Table 3, the percentage recovery for the mushroom samples lied in the range $91.96 \pm 3.32 \%-103.84 \pm 4.82 \%$, which are within the acceptable range for all metals (EC 2010). Similarly, for the substrate samples, Table 4, the recoveries obtained were found to vary from $87.76 \pm 1.25$ to $104.52 \pm 0.72 \%$, which are again within the acceptable range for all metals (EC 2010).

\section{Metal contents in the mushrooms}

The mean concentrations of essential and non-essential metals are presented in Table 2 for the samples digested by the three different digestion methods. All metal concentrations were determined on a dry weight basis as $\mathrm{mg} / \mathrm{kg}$. Among the investigated six essential and nonessential metal elements, all were found to be above the method detection limit, except for cadmium and lead, which were not detected in the mushroom (Pleurotus ostreatus and Pleurotus florida) and their respective substrate samples.

Copper is essential metal, which serve as a constituent of some metalloenzymes, and is required in hemoglobin synthesis and catalysis of metabolic growth (Silvestre et al. 2000). It was detected both in the fruiting body of the mushroom samples with varying concentrations. Pleurotus florida contained the highest amount $(53.56 \pm 0.82 \mathrm{mg} / \mathrm{kg})$ of copper while least concentration was exhibited in the Pleurotus ostreatus sample $(51.19 \pm 1.36 \mathrm{mg} / \mathrm{kg})$ (Table 2). The average copper content of the analyzed mushroom samples was $52.38 \mathrm{mg} / \mathrm{kg}$, which are above the safe limit of $40 \mathrm{mg} / \mathrm{kg}$ set by WHO (1982) in foods. According to the review reported by Kalac (2010), copper concentrations accumulated in mushroom species were usually varied from 20.0 to $100.0 \mathrm{mg} / \mathrm{kg}$. Other workers have also 
Table 1 LOD and LOQ for the method of analysis of the mushroom and substrate samples

\begin{tabular}{lccccc}
\hline Element & $\mathrm{IDL}^{\mathrm{a}}(\mathrm{mg} / \mathrm{L})$ & $\mathrm{LOD}$ for mushroom $(\mathrm{mg} / \mathrm{L})$ & $\mathrm{LOD}$ for substrate $(\mathrm{mg} / \mathrm{L})$ & $\mathrm{LOQ}$ for mushroom $(\mathrm{mg} / \mathrm{L})$ & $\mathrm{LOQ}$ for substrate $(\mathrm{mg} / \mathrm{L})$ \\
\hline $\mathrm{Cu}$ & 0.020 & 0.053 & 0.074 & 0.175 & 0.248 \\
$\mathrm{Fe}$ & 0.030 & 0.345 & 0.176 & 1.149 & 0.588 \\
$\mathrm{Zn}$ & 0.005 & 0.017 & 0.016 & 0.055 & 0.053 \\
$\mathrm{Mn}$ & 0.001 & 0.070 & 0.195 & 0.233 & 0.649 \\
$\mathrm{Cd}$ & 0.005 & 0.013 & 0.014 & 0.042 & 0.046 \\
$\mathrm{~Pb}$ & 0.100 & 0.385 & 0.231 & 1.283 & 0.770 \\
\hline
\end{tabular}

${ }^{a}$ Instrumental detection limit

presented copper contents of the mushroom samples in the literature to be in the ranges: $16.1-144.9 \mathrm{mg} / \mathrm{kg}$ (Elekes et al. 2010), $2.6-72.4 \mathrm{mg} / \mathrm{kg}$ (Sen et al. 2012), $1.8-22.3 \mathrm{mg} / \mathrm{kg}$ (Okwulehie and Ogoke 2013), $5.0-83.0 \mathrm{mg} / \mathrm{kg}$ (Uzun et al. 2011) and $13.7-182.4 \mathrm{mg} / \mathrm{kg}$ (George et al. 2014). The results obtained, in the current study, indicated that copper content of the investigated mushroom samples were found to be comparable with those reported in the literature.

The iron content of the investigated mushroom samples of this study ranged from $220.87 \pm 18.70 \mathrm{mg} / \mathrm{kg}$ in Pleurotus ostreatus to $243.92 \pm 6.92 \mathrm{mg} / \mathrm{kg}$ in Pleurotus florida (Table 2). The average concentration of iron in the analyzed mushroom samples was $232.40 \mathrm{mg} / \mathrm{kg}$, which was above the safe limit of $15 \mathrm{mg} / \mathrm{kg}$ set by WHO (1982). Based on the results from papers published until 1999, reported iron content was found to vary between 30.0 and $150.0 \mathrm{mg} / \mathrm{kg}$ (Kalac and Svoboda 2000). Similarly, iron contents determined in mushroom samples, during the recent years, were reported in the range of 44.4 - $125.1 \mathrm{mg} / \mathrm{kg}$ (George et al. 2014), 101.6 $543.8 \mathrm{mg} / \mathrm{kg}$ (Radulescu et al. 2010), $1322.4-1596.0 \mathrm{mg} / \mathrm{kg}$ (Naresh et al. 2012), $139.0-1714.0 \mathrm{mg} / \mathrm{kg}$ (Sarikurkcu et al. 2011), $43.7-65.1 \mathrm{mg} / \mathrm{kg}$ (Quarcoo and Adotey 2013) and $8.25-58.25 \mathrm{mg} / \mathrm{kg}$ (Udochukwu et al. 2014), which could possibly be due to increased use of iron associated with increased industrialization. Thus, amount of iron obtained, in the present study, are in good agreement with the reported values in the literature. It is known that adequate iron in a diet is very important in order to decrease the incidence of anemia.

Zinc is one of the most important mineral needed by our body systems due to the fact that it is highly associated with protein and carbohydrate rich foods. Zinc is also used in medicines that treat rashes, acne, dandruff and athlete's foot (Okwulehie and Ogoke 2013). It has biological significances for living organisms and mushrooms are known as good zinc accumulators (Isiloglu

Table 2 Mean concentration ( $n=3, \bar{x} \pm$ SD mg/kg dry weight) and \%RSD of metals in mushroom and substrate samples

\begin{tabular}{|c|c|c|c|c|c|c|c|c|c|c|c|}
\hline \multirow[t]{2}{*}{ Digestion methods } & \multirow[t]{2}{*}{ Species } & \multicolumn{2}{|l|}{$\mathrm{Cu}$} & \multicolumn{2}{|l|}{$\mathrm{Fe}$} & \multicolumn{2}{|l|}{$\mathrm{Zn}$} & \multicolumn{2}{|l|}{$\mathrm{Mn}$} & \multirow[t]{2}{*}{$\mathrm{Cd}$} & \multirow[t]{2}{*}{$\mathrm{Pb}$} \\
\hline & & Mean \pm SD & $\% \mathrm{RSD}$ & Mean \pm SD & $\% \mathrm{RSD}$ & Mean \pm SD & $\%$ RSD & Mean \pm SD & $\% \mathrm{RSD}$ & & \\
\hline \multirow[t]{4}{*}{ Dry ashing } & $\mathrm{PO}$ & $49.65 \pm 1.75$ & 3.53 & $200.12 \pm 6.64$ & 3.32 & $87.07 \pm 0.75$ & 0.87 & $46.08 \pm 2.33$ & 5.05 & ND & ND \\
\hline & Substrate & $45.38 \pm 2.86$ & 6.30 & $287.18 \pm 5.88$ & 2.05 & $60.94 \pm 0.72$ & 0.18 & $56.28 \pm 3.75$ & 6.66 & ND & ND \\
\hline & PF & $52.68 \pm 3.51$ & 6.66 & $234.60 \pm 6.64$ & 2.83 & $93.60 \pm 1.83$ & 1.95 & $39.36 \pm 2.33$ & 5.92 & ND & ND \\
\hline & Substrate & $49.51 \pm 4.29$ & 8.66 & $257.70 \pm 6.66$ & 2.59 & $63.24 \pm 1.11$ & 1.75 & $60.61 \pm 3.75$ & 6.19 & ND & ND \\
\hline \multirow[t]{4}{*}{ Wet digestion } & $\mathrm{PO}$ & $51.67 \pm 3.04$ & 5.88 & $226.05 \pm 6.64$ & 2.94 & $90.68 \pm 0.96$ & 1.06 & $47.04 \pm 4.66$ & 9.90 & ND & ND \\
\hline & Substrate & $50.33 \pm 5.15$ & 10.24 & $301.28 \pm 4.44$ & 1.47 & $62.67 \pm 0.20$ & 0.32 & $58.44 \pm 6.49$ & 11.11 & ND & ND \\
\hline & PF & $53.70 \pm 1.75$ & 3.27 & $245.21 \pm 6.64$ & 2.71 & $94.43 \pm 1.83$ & 1.93 & $41.67 \pm 4.66$ & 11.17 & ND & ND \\
\hline & Substrate & $52.81 \pm 3.78$ & 7.16 & $266.67 \pm 5.88$ & 2.20 & $64.05 \pm 0.40$ & 0.62 & $62.77 \pm 3.75$ & 5.97 & ND & ND \\
\hline \multirow[t]{4}{*}{ Microwave digestion } & $\mathrm{PO}$ & $52.25 \pm 1.81$ & 3.46 & $236.43 \pm 6.71$ & 2.84 & $91.29 \pm 0.93$ & 1.02 & $49.53 \pm 2.32$ & 4.68 & ND & ND \\
\hline & Substrate & $51.20 \pm 4.79$ & 9.35 & $310.08 \pm 6.71$ & 2.17 & $64.04 \pm 0.20$ & 0.32 & $60.24 \pm 4.02$ & 6.67 & ND & ND ND \\
\hline & PF & $54.34 \pm 1.81$ & 3.33 & $251.94 \pm 6.71$ & 2.66 & $97.76 \pm 0.54$ & 0.55 & $42.84 \pm 2.32$ & 5.41 & ND & ND \\
\hline & Substrate & $53.29 \pm 3.14$ & 5.88 & $271.32 \pm 6.71$ & 2.44 & $65.45 \pm 0.41$ & 0.62 & $64.26 \pm 4.02$ & 6.25 & ND & ND \\
\hline \multirow[t]{4}{*}{ Mean total } & $\mathrm{PO}$ & $51.19 \pm 1.36$ & 2.67 & $220.87 \pm 18.70$ & 8.47 & $89.68 \pm 2.28$ & 2.54 & $47.55 \pm 1.78$ & 3.74 & ND & ND \\
\hline & Substrate & $48.97 \pm 3.14$ & 6.41 & $299.51 \pm 11.55$ & 3.86 & $62.55 \pm 1.55$ & 2.48 & $58.32 \pm 1.98$ & 3.40 & ND & ND \\
\hline & PF & $53.56 \pm 0.82$ & 1.54 & $243.92 \pm 8.74$ & 3.58 & $95.26 \pm 2.20$ & 2.31 & $41.29 \pm 1.77$ & 4.29 & ND & ND \\
\hline & Substrate & $51.87 \pm 2.06$ & 3.97 & $265.23 \pm 6.92$ & 2.61 & $64.25 \pm 1.12$ & 1.74 & $62.55 \pm 1.84$ & 2.93 & ND & ND \\
\hline
\end{tabular}


Table 3 Values of the recovery analysis ( $\%$ R $\pm \mathrm{SD}, n=3)$ for mushroom samples

\begin{tabular}{|c|c|c|c|c|c|c|c|}
\hline \multirow[t]{2}{*}{ Metals } & & \multicolumn{2}{|l|}{ Dry ashing } & \multicolumn{2}{|l|}{ Wet digestion } & \multicolumn{2}{|c|}{ Microwave digestion } \\
\hline & & $\mathrm{PO}$ & PF & $\mathrm{PO}$ & PF & $\mathrm{PO}$ & PF \\
\hline \multirow[t]{3}{*}{$\mathrm{Cu}$} & $C^{M}$ & 49.65 & 52.68 & 51.67 & 53.70 & 52.25 & 54.34 \\
\hline & $A R$ & $74.46 \pm 2.41$ & $78.64 \pm 1.21$ & $75.16 \pm 3.62$ & $77.94 \pm 5.25$ & $75.24 \pm 8.30$ & $78.37 \pm 6.27$ \\
\hline & $\% R$ & $99.24 \pm 0.96$ & $103.84 \pm 4.82$ & $93.96 \pm 1.45$ & $96.96 \pm 2.10$ & $91.96 \pm 3.32$ & $96.12 \pm 0.63$ \\
\hline \multirow[t]{3}{*}{$\mathrm{Fe}$} & $\mathrm{C}^{\mathrm{M}}$ & 200.12 & 234.60 & 226.05 & 245.21 & 236.43 & 251.94 \\
\hline & $A R$ & $340.07 \pm 3.86$ & $382.16 \pm 1.46$ & $380.47 \pm 5.26$ & $392.26 \pm 5.26$ & $375.97 \pm 13.43$ & $395.35 \pm 11.63$ \\
\hline & $\% R$ & $93.30 \pm 2.57$ & $98.37 \pm 0.97$ & $102.95 \pm 3.50$ & $98.03 \pm 3.50$ & $93.03 \pm 0.89$ & $95.61 \pm 0.78$ \\
\hline \multirow[t]{3}{*}{$\mathrm{Zn}$} & $C^{M}$ & 87.07 & 93.60 & 90.68 & 94.43 & 91.29 & 97.76 \\
\hline & $A R$ & $97.05 \pm 1.07$ & $103.28 \pm 0.51$ & $100.17 \pm 0.88$ & $104.29 \pm 0.51$ & $100.58 \pm 0.89$ & $107.04 \pm 1.81$ \\
\hline & $\% R$ & $99.80 \pm 1.07$ & $96.80 \pm 0.51$ & $94.90 \pm 0.88$ & $98.60 \pm 0.51$ & $92.90 \pm 0.88$ & $92.80 \pm 1.81$ \\
\hline \multirow[t]{3}{*}{$\mathrm{Mn}$} & $\mathrm{C}^{\mathrm{M}}$ & 46.08 & 39.36 & 47.04 & 41.67 & 49.53 & 42.84 \\
\hline & $A R$ & $148.15 \pm 3.26$ & $136.04 \pm 1.23$ & $148.86 \pm 8.09$ & $141.74 \pm 4.45$ & $141.90 \pm 4.64$ & $137.23 \pm 9.64$ \\
\hline & $\% R$ & $102.07 \pm 3.26$ & $96.68 \pm 1.23$ & $101.82 \pm 0.81$ & $100.07 \pm 4.45$ & $92.37 \pm 0.93$ & $94.39 \pm 0.96$ \\
\hline
\end{tabular}

$C^{M}$ Concentration in the Mushroom, AR Amount Recovered, \%R Percent Recovery

et al. 2001). Zinc was found in all the analyzed fruiting body of the mushrooms with concentration ranging from $89.68 \pm 2.28 \mathrm{mg} / \mathrm{kg}$ in Pleurotus ostreatus and $95.26 \pm 2.20 \mathrm{mg} / \mathrm{kg}$ in Pleurotus florida (Table 2). The average zinc content of the analyzed mushroom samples was $92.47 \mathrm{mg} / \mathrm{kg}$. The values for zinc in the investigated mushroom samples were above the permissible limit of $60 \mathrm{mg} / \mathrm{kg}$ recommended values in foods (WHO 1982). Zinc concentrations of edible mushroom samples in the literature have been reported to be: 26.7 - $186.0 \mathrm{mg} / \mathrm{kg}$ (Genccelep et al. 2009), 19.0 - $49.7 \mathrm{mg} / \mathrm{kg}$ (George et al. 2014), 5.7 - $97.5 \mathrm{mg} / \mathrm{kg}$ (Sen et al. 2012), 29.0 $146.0 \mathrm{mg} / \mathrm{kg}$ (Sarikurkcu et al. 2011), $27.8-70.9 \mathrm{mg} / \mathrm{kg}$ (Okwulehie and Ogoke 2013) and 6.4-27.33 mg/kg
(Udochukwu et al. 2014). This reveals that the findings of this study are in good agreement with the results reported for similar studies.

Manganese is an essential metal needed for biological systems such as metalloproteins (Unak et al. 2007). The manganese content of the mushrooms studied, in the present work, was found to vary from $47.55 \pm 1.78 \mathrm{mg} / \mathrm{kg}$ in Pleurotus ostreatus to $41.29 \pm 1.77 \mathrm{mg} / \mathrm{kg}$ in Pleurotus florida (Table 2). The average manganese content of the analyzed samples was $44.42 \mathrm{mg} / \mathrm{kg}$, which is far below the toxicity limit between 400 and $1000 \mathrm{mg} / \mathrm{kg}$ of manganese (WHO 1982). Usual manganese content in mushrooms varies between 10.0 and $60.0 \mathrm{mg} / \mathrm{kg}$ (Kalac 2010). Similar earlier studies have also indicated manganese contents in

Table 4 Values of the recovery analysis ( $\% \mathrm{R} \pm \mathrm{SD}, n=3)$ for substrate samples

\begin{tabular}{|c|c|c|c|c|c|c|c|}
\hline \multirow[t]{2}{*}{ Metals } & & \multicolumn{2}{|l|}{ Dry ashing } & \multicolumn{2}{|l|}{ Wet digestion } & \multicolumn{2}{|c|}{ Microwave digestion } \\
\hline & & $\mathrm{PO}$ & PF & $\mathrm{PO}$ & PF & $\mathrm{PO}$ & PF \\
\hline \multirow[t]{3}{*}{$\mathrm{Cu}$} & $C^{S}$ & 45.38 & 49.51 & 50.33 & 52.81 & 51.20 & 53.29 \\
\hline & AR & $69.59 \pm 2.41$ & $72.37 \pm 3.20$ & $74.46 \pm 4.35$ & $77.24 \pm 3.62$ & $77.33 \pm 1.81$ & $75.23 \pm 3.14$ \\
\hline & $\% R$ & $96.84 \pm 0.96$ & $91.44 \pm 1.28$ & $96.52 \pm 1.74$ & $97.72 \pm 1.45$ & $104.52 \pm 0.72$ & $87.76 \pm 1.25$ \\
\hline \multirow[t]{3}{*}{$\mathrm{Fe}$} & $c^{S}$ & 287.18 & 257.70 & 301.28 & 266.67 & 310.08 & 275.19 \\
\hline & $A R$ & $430.14 \pm 5.83$ & $405.72 \pm 6.36$ & $451.18 \pm 3.86$ & $414.98 \pm 1.46$ & $457.36 \pm 6.71$ & $418.61 \pm 11.63$ \\
\hline & $\% R$ & $95.31 \pm 3.89$ & $98.68 \pm 4.24$ & $99.93 \pm 2.57$ & $98.87 \pm 0.97$ & $98.19 \pm 4.48$ & $95.61 \pm 0.78$ \\
\hline \multirow[t]{3}{*}{$\mathrm{Zn}$} & $C^{S}$ & 60.94 & 63.24 & 62.67 & 64.05 & 64.04 & 65.45 \\
\hline & $A R$ & $70.90 \pm 1.02$ & $72.90 \pm 2.27$ & $71.90 \pm 0.70$ & $74.01 \pm 1.68$ & $73.90 \pm 1.08$ & $74.96 \pm 0.73$ \\
\hline & $\% R$ & $99.60 \pm 1.02$ & $96.60 \pm 2.27$ & $92.30 \pm 0.69$ & $99.60 \pm 1.68$ & $98.60 \pm 1.08$ & $95.10 \pm 0.73$ \\
\hline \multirow[t]{3}{*}{$\mathrm{Mn}$} & $C^{S}$ & 56.28 & 60.61 & 58.44 & 62.77 & 60.24 & 64.26 \\
\hline & $A R$ & $153.13 \pm 6.53$ & $161.68 \pm 6.53$ & $155.27 \pm 4.45$ & $160.97 \pm 4.45$ & $156.63 \pm 6.96$ & $163.32 \pm 9.28$ \\
\hline & $\% R$ & $96.85 \pm 0.65$ & $101.07 \pm 0.65$ & $96.83 \pm 4.44$ & $98.2 \pm 4.44$ & $96.39 \pm 0.69$ & $99.06 \pm 0.92$ \\
\hline
\end{tabular}

$C^{S}$ Concentration in the Substrate, $A R$ Amount Recovered, \%R Percent Recovery 
the mushrooms samples vary as follow: $29.5-46.8 \mathrm{mg} / \mathrm{kg}$ (Li et al. 2011), $7.2-55.6 \mathrm{mg} / \mathrm{kg}$ (Ouzouni et al. 2009), 37.9 - $38.7 \mathrm{mg} / \mathrm{kg}$ (Mleczek et al. 2013), 0.7 - $4.2 \mathrm{mg} / \mathrm{kg}$ (Radulescu et al. 2010), $2.2-48.5 \mathrm{mg} / \mathrm{kg}$ (George et al. 2014) and $1.3-47.5 \mathrm{mg} / \mathrm{kg}$ (Sen et al. 2012). Concentrations of manganese determined, in this study, are also in good agreement with the results reported in the literature.

Cadmium is accumulated mainly in kidneys, spleen and liver and its blood serum level increases considerably following mushroom consumption (Kalac and Svoboda 2000). Thus, cadmium seems to be the most deleterious among heavy metals in the mushrooms. Lead is similar to Cadmium having no beneficial effect in human metabolism, producing progressive toxicity. Lead can reach humans through air, water, and food. It accumulates in bones and can take in the role of calcium. Lead creates health disorders such as sleeplessness, tiredness, hearing, and weight loss (Udochukwu et al. 2014). Fortunately, the concentrations of the toxic heavy metals, cadmium and lead, in the studied mushroom samples were too low to be detected by the analytical technique used in this study. According to FAO/WHO (Kalac 2010) tolerable weekly intake of cadmium and lead are 0.007 and $0.025 \mathrm{mg} / \mathrm{kg}$ body weight, respectively. The lead and cadmium levels in all studied species are very low and thus, these mushroom species are safe for consumption against the risk of these metals.

The difference in values found in this study as compared to the values determined in other studies can be attributed to various factors such as the analytical methods used and the substrate on which they were cultivated. Mushrooms are known to undergo very effective mechanism that enables them to readily take up some heavy metals from the ecosystem (Zhu et al. 2011). The accumulation of heavy metals in the mushrooms seems to be affected by environmental and fungal related factors. Environmental factors such as organic matter content, $\mathrm{pH}$ and metal concentration in substrate and fungal factors such as the species, morphological part of the fruit body, developmental stages, age of the mycelium, intervals between fructifications and biochemical composition contribute significantly to the amount of heavy metals in the mushroom samples (Radulescu et al. 2010).

\section{Metal contents in the substrates}

As shown in Table 2, the mean concentration of copper in Pleurotus florida substrate was the highest $(51.87 \pm 2.06 \mathrm{mg} / \mathrm{kg})$ and least in Pleurotus ostreatus $(48.97 \pm 3.14 \mathrm{mg} / \mathrm{kg})$. The concentrations of copper found in the substrate samples for both mushroom samples are comparable. Similarly, comparable concentrations of iron were also found in the substrate of all study samples; $299.51 \pm 11.55 \mathrm{mg} / \mathrm{kg}$ in Pleurotus ostreatus substrate and $265.23 \pm 6.92 \mathrm{mg} / \mathrm{kg}$ for Pleurotus florida (Table 2).
The concentration of zinc in the substrate samples is $62.55 \pm 1.55 \mathrm{mg} / \mathrm{kg}$ and $64.25 \pm 1.12 \mathrm{mg} / \mathrm{kg}$ for Pleurotus ostreatus and Pleurotus florida, respectively (Table 2). The concentration of manganese in the substrate sample is the highest in Pleurotus florida $(62.55 \pm 1.84 \mathrm{mg} / \mathrm{kg})$ and the least in Pleurotus ostreatus (58.32 $\pm 1.98 \mathrm{mg} / \mathrm{kg}$ ) (Table 2). On the other hand, concentrations of the toxic heavy metals, cadmium and lead, in the studied substrates were too low to be detected by the analytical technique used in the study. The mean concentration of metals in the substrate samples followed the decreasing order of: Fe > $\mathrm{Zn}>\mathrm{Mn}>\mathrm{Cu}>\mathrm{Cd}$ and $\mathrm{Pb}$ both for Pleurotus ostreatus and Pleurotus florida.

In order to better understand the general characteristics of the substrates, in relation to the sites where the fruiting bodies were harvested, $\mathrm{pH}$ and humidity of the substrate have been determined. Accordingly, the humidity of the analyzed substrate samples possess relatively higher mean value, i.e. $74.80 \%$, which could be attributed to high moisture content of the analyzed substratum (wheat straw). The substrate $\mathrm{pH}$ was also found to be 6.87 , which might probably be related to greater contents of biological materials. The mean content of trace metals, for example zinc, in the substrate was found to be comparable to the normal value detected in organic soil $(57.0-100.0 \mathrm{mg} / \mathrm{kg})$, and did not reached this limit for copper $(1.0-115.0 \mathrm{mg} / \mathrm{kg})$ (Elekes et al. 2010).

\section{The bioaccumulation factor}

The ability of mushrooms to accumulate elements from the substrates is expressed by bio-concentration factor (BCF), i.e., the ratio of the elemental content in the fruiting body to the content in underlying substrate (both in dry matter). In this context, more information is necessary from which substrate horizons the individual mushroom species takes their nutrients. It is usually the uppermost layer of $10 \mathrm{~cm}$ depth which is being sampled and analyzed for trace elements because this layer of the substrate contains mainly organic debris. However, mycelium of some mushroom species, e.g. Suillus luteus, is also associated with mineral horizons (Tedersoo et al. 2003). The coefficient of accumulation factor (BCF) of the heavy metals is calculated using the following relation:

$$
\mathrm{BCF}=\frac{\text { Concentration of heavy metal in Mushroom }}{\text { Concentration of heavy metal in Substrate }}
$$

The accumulation factors of the target heavy metals in the mushroom samples were calculated as 1.047, 0.736, 1.434 and 0.815 in Pleurotus ostreatus; and 1.034, 0.920, 1.483 and 0.660 in Pleurotus florida for $\mathrm{Cu}, \mathrm{Fe}, \mathrm{Zn}$ and $\mathrm{Mn}$, respectively. The corresponding results are shown in Table 5. Metal bio-accumulation factors in this study 
Table 5 Mean bio-accumulation factors of heavy metals from substrate to mushrooms

\begin{tabular}{lllll}
\hline Species & $\mathrm{Cu}$ & $\mathrm{Fe}$ & $\mathrm{Zn}$ & $\mathrm{Mn}$ \\
\hline Pleurotus ostreatus & 1.047 & 0.736 & 1.434 & 0.815 \\
Pleurotus florida & 1.034 & 0.920 & 1.483 & 0.660 \\
\hline
\end{tabular}

are comparable with those reported by Blanusa et al. (2001), Racz and Oldal (2000), Radulescu et al. (2010) and Stihi et al. (2011). While $\mathrm{Cu}$ and $\mathrm{Zn}$ being accumulated at higher ratios by the mushrooms, the other elements being accumulated at relatively lesser ratios.

\section{Mushroom percentage contribution for daily needs in human body}

Based on the mineral contents of the mushroom species, it is converted on the scale for $100 \mathrm{~g}$ fresh mushroom (based on the $90 \%$ moisture content). This eventually signifies the minerals available in $100 \mathrm{~g}$ fresh mushrooms that can be consumed per day. The situation becomes quite practical when $100 \mathrm{~g}$ of fresh mushroom is consumed at least four or five times a week. Recommended dietary allowances (RDA) and tolerable upper intake levels (UL), that is likely to pose no risk of adverse health effects, of the metals along with relevant references are presented in Table 6.

The concentrations of these essential metals reported to $100 \mathrm{~g}$ of fresh weight are calculated in Table 7, and in Table 8 also listed the percentage of these amounts in the daily physiological necessary for an adult. Based on these results, Pleurotus florida has the higher contribution of minerals in the daily necessary than Pleurotus ostreatus in $100 \mathrm{~g}$ of fresh mushrooms. The calculated percentage contributions of essential metals in this study are comparable with the data reported in Elekes and Dumitru (2010). $\mathrm{Cu}$ and $\mathrm{Zn}$ were accumulated at a relatively higher ratio by the mushroom samples while the other elements were being accumulated at a moderate ratio. Copper have greater contributions, $40.0 \%$ to $53.3 \%$, which is also important for the daily nutrition of humans.

\section{Statistical analysis}

In this study, the fruiting body of the mushroom and substrate samples were digested by three different

Table 6 Recommended Daily Intake (RDI) and Tolerable Upper intake Limit (UL) of essential elements

\begin{tabular}{llll}
\hline Element & RDA & UL & Reference \\
\hline Copper (Cu) & $0.9 \mathrm{mg} /$ day & $10.0 \mathrm{mg} /$ day & Ross et al. 2011 \\
Iron (Fe) & $8.0-18.0 \mathrm{mg} /$ day & $45.0 \mathrm{mg} /$ day & Ross et al. 2011 \\
Zinc (Zn) & $8.0-11.0 \mathrm{mg} /$ day & $40.0 \mathrm{mg} /$ day & Ross et al. 2011 \\
Manganese (Mn) & $1.8-2.3 \mathrm{mg} /$ day & $11.0 \mathrm{mg} /$ day & Ross et al. 2011 \\
\hline
\end{tabular}

Table 7 Concentrations of the essential metals in the studied mushrooms samples (mg/100 $\mathrm{g}$ of fresh weight)

\begin{tabular}{lllll}
\hline Species & $\mathrm{Cu}$ & $\mathrm{Fe}$ & $\mathrm{Zn}$ & $\mathrm{Mn}$ \\
\hline Pleurotus ostreatus & 0.36 & 1.57 & 0.64 & 0.34 \\
Pleurotus florida & 0.48 & 2.20 & 0.86 & 0.37 \\
\hline
\end{tabular}

digestion methods (dry, wet and microwave). Each sample was mixed thoroughly and one representative bulk sample was taken for each kind of samples. To this end, three aliquots were taken from each bulk sample and then digested and analyzed. During these processes, a number of random errors might be introduced in each aliquot and in each replicate measurement. There may be differences in results of the analysis between different mushroom samples within and between groups. Therefore, depending upon the type and the nature of results, there are different statistical methods used to check whether differences could occur between the results of analysis or not; and if there is a difference, statistical analysis signifies whether the difference is significant or not. Of these, one-way analysis of variance (ANOVA) has been selected for indicating the differences (Miller and Miller 2010).

Moreover, analysis of variance (ANOVA) is used to test hypothesis about differences between two or more means. For the present study, the significance of variation within three digestion methods has been calculated using one-way ANOVA. Microsoft Excel has also used to calculate the presence or absence of significant difference in mean concentration of each metal between different kinds of mushroom samples, substrate samples and digestion methods.

\section{Statistical analysis of the mushroom samples}

For Pleurotus ostreatus and Pleurotus florida mushroom samples, one way ANOVA has showed that except for copper $(p=0.580, p=0.185)$ and manganese $(p=0.314$, $p=0.213)$, respectively, the concentrations of iron and zinc have $(p<0.05)$ overall significant at $95 \%$ confidence interval. The least significant difference (LSD) value was calculated for all metals and compared with the difference between the means of the metal contents between the three digestion methods. For zinc, all means differ significantly from each other while for copper and manganese, all the means were not differing significantly. For iron, all the means were found to differ significantly

Table 8 The percentage contribution for the daily necessary in human body

\begin{tabular}{lllll}
\hline Species & $\mathrm{Cu}$ & $\mathrm{Fe}$ & $\mathrm{Zn}$ & $\mathrm{Mn}$ \\
\hline Pleurotus ostreatus & $40.0 \%$ & $8.7-19.6 \%$ & $5.8-8.0 \%$ & $14.7-18.9 \%$ \\
Pleurotus florida & $53.3 \%$ & $12.2-27.5 \%$ & $7.8-10.7 \%$ & $16.1-20.5 \%$ \\
\hline
\end{tabular}


except the mean of the wet digestion which was not differing significantly from microwave digestion.

Obviously, presence of the significant difference between the means may be associated with the different digestion methods employed for sample preparation. The differences in the contents of some of the metals have been reported to be heavily dependent upon the composition of the substrate from which the mushrooms got their nutrients, the site where the samples collected from, age of the fruiting bodies and mycelium, and distance from the source of pollution (Kalac et al. 1991; Radulescu et al. 2010). Similarly, presence of significant difference in concentration for some minerals may indicate that either the studied samples contain higher concentration of mineral nutrients in the substrate or a well-aged mushroom has been harvested and good precautions have been followed during processing.

\section{Statistical analysis of the substrate samples}

For Pleurotus ostreatus substrate sample, a one way ANOVA showed that except for copper $(p=0.06)$, the concentrations of iron, zinc and manganese were $(p<0.05)$ overall significant at $95 \%$ confidence interval. The least significant difference (LSD) value was also calculated for all metals and compared with the difference between the means of the metal contents between the three digestion methods. For iron, all means differ significantly from each other while for copper all means don't differ significantly except for dry ashing with microwave digestion. For zinc and manganese, all means differ significantly except for the mean of the wet digestion which was not found to differ significantly from the microwave digestion.

For Pleurotus florida substrate sample, a one way ANOVA shows that except for copper $(p=0.08)$, the concentrations of iron, zinc and manganese were $(p<0.05)$ overall significant at $95 \%$ confidence interval. The least significant difference (LSD) values were also calculated for all metals and compared with the differences between the means of the metal contents between the three digestion methods. For copper, iron, zinc and manganese, all the means were found to differ significantly from each other except for the mean of the wet digestion which was not noted to differ significantly from the microwave digestion.

\section{Comparison of metal content of the current study with earlier reported results}

There are several studies carried out on analysis of the metal contents of different mushroom species, in different countries of the world. Therefore, it is reasonable to compare the results obtained from the analysis of the mushroom species considered in this study with the values reported, in the literature, for other mushroom species analyzed elsewhere. The outcome of this comparison may help to identify the possible differences in composition and if there exists a deviation from certain guide lines. To this end, comparison of metal concentrations in the Ethiopian mushroom species with those reported from other countries has been done and given in Table 9.

The levels of copper in the currently analyzed species ranged from 51.19 to $53.56 \mathrm{mg} / \mathrm{kg}$. The observed copper concentrations were higher than those reported from other countries for different mushroom species except for the result reported by Ouzouni et al. 2009 from Greece. The amount of iron determined in this study was higher than those reported from China (Zhu et al. 2011), Greece (Ouzouni et al. 2009), USA (George et al. 2014) and Nigeria (Udochukwu et al. 2014). However, the levels of iron found in the presently analyzed species were comparable with those reported from Romania

Table 9 Comparison of metal concentration (mg/kg dry weight) of different mushroom species from different countries

\begin{tabular}{|c|c|c|c|c|c|c|c|c|}
\hline \multirow[t]{2}{*}{ Country } & \multirow[t]{2}{*}{ Species } & \multicolumn{6}{|c|}{ Concentration (mg/kg dry weight) of metals in mushrooms } & \multirow[t]{2}{*}{ References } \\
\hline & & $\mathrm{Cu}$ & $\mathrm{Fe}$ & $\mathrm{Zn}$ & $\mathrm{Mn}$ & $\mathrm{Cd}$ & $\mathrm{Pb}$ & \\
\hline Turkey & Pleurotus sajur-caju & 8.0 & 533.0 & 35.0 & 5.1 & ND & ND & Akyuz and Kirbag 2010 \\
\hline Poland & Rozites caperatus & 66.3 & 329.9 & 152.5 & 38.3 & 3.98 & 1.20 & Mleczek et al. 2013 \\
\hline China & Agaricus bisporus & 14.8 & 190.0 & 81.4 & 28.8 & 0.35 & 2.2 & Zhu et al. 2011 \\
\hline India & Agaricus bisporus & 7.4 & 1596.0 & 46.8 & 16.7 & 0.14 & 0.75 & Naresh et al. 2012 \\
\hline \multirow[t]{2}{*}{ Nigeria } & Polyporus frondosis & 19.45 & - & 38.05 & 18.04 & 0.47 & 0.95 & Ita et al. 2008 \\
\hline & Plerotussquarrosulus & 1.75 & 33.2 & 16.9 & - & 3.56 & 1.56 & Udochukwu et al. 2014 \\
\hline USA & Lentinula edodes & 10.9 & 36.7 & 34.4 & 25.3 & 1.98 & 1.26 & George et al. 2014 \\
\hline \multirow[t]{2}{*}{ Romania } & Lycoperdon Perlatum & 11.8 & 623.0 & 127.0 & 12.6 & 1.64 & 0.71 & Stihi et al. 2011 \\
\hline & Agaricus campestris & 10.0 & 261.7 & 96.6 & 2.4 & 0.19 & 1.56 & Radulescu et al. 2010 \\
\hline Greece & Lepista nuda & 75.06 & 74.6 & 98.99 & 33.65 & 0.25 & 1.16 & Ouzouni et al. 2009 \\
\hline Ethiopia & Pleurotus ostreatus & 51.19 & 220.87 & 89.68 & 47.55 & ND & ND & This study \\
\hline Ethiopia & Pleurotus florida & 53.56 & 243.92 & 95.26 & 41.29 & ND & ND & This study \\
\hline
\end{tabular}


(Stihi et al. 2011; Radulescu et al. 2010), Poland (Mleczek et al. 2013) and Turkey (Akyuz and Kirbag 2010) for other mushroom species. Zinc is present in appreciable amount in the mushroom species analyzed. The observed concentrations of zinc were higher than those mushroom species from China (Zhu et al. 2011), Nigeria (Ita et al. 2008; Udochukwu et al. 2014), India (Naresh et al. 2012), USA (George et al. 2014) and Turkey (Akyuz and Kirbag 2010). The zinc concentrations in the studied samples were found to be in agreement with those obtained from Romania (Stihi et al. 2011; Radulescu et al. 2010) and Greece (Ouzouni et al. 2009). The amount of manganese determined in the current study was also in good agreement with the ones reported from different countries for different mushroom species; corresponding results given in Table 9. Regarding the non-essential metals $(\mathrm{Cd}$ and $\mathrm{Pb})$, in most mushroom species, the amounts of cadmium and lead were detected at very low concentration levels. Similarly, in the present study, the levels of these two metals were found to be below their detection limits.

As has also been indicated above, the results obtained in the presented study were noted to be favorably comparable with the reported findings. However, results for some metals from mushroom species considered, in this study, were observed to differ greatly. This difference in the contents of the metals could be associated to the variation in the composition of the substrate from which the mushrooms got their nutrients, the site where the samples collected from, age of the fruiting bodies and mycelium, and distance from the source of pollution (Kalac et al. 1991; Radulescu et al. 2010). Besides, the metal concentrations in the mushroom samples could also mainly be affected by the $\mathrm{pH}$ or organic matter content of the substrates (Gast et al. 1988; Demirbas 2002).

\section{Conclusions}

The levels of essential and non-essential metals, viz., $\mathrm{Cu}$, $\mathrm{Fe}, \mathrm{Zn}, \mathrm{Mn}, \mathrm{Cd}$ and $\mathrm{Pb}$ in the fruiting bodies of the two oyster mushroom species (Pleurotus ostreatus and Pleurotus florida) and their respective substrate samples have been analyzed utilizing flame atomic absorption spectrometry after digesting the samples employing dry ashing, wet digestion and microwave digestion techniques. The use of microwave digestion system provides very fast, safer, simpler and cleaner sample preparation method than both dry ashing and wet digestion method.

The levels of metals analyzed in the samples were also compared with those reported in the literature. It was observed, in the present study, that the detected levels of copper, zinc, iron, and manganese were generally in agreement with the reported results. The uptake of metals by the mushroom samples may be different from one species to others and their respective substrates, in many ways. Mushrooms accumulate $\mathrm{Zn}$ and $\mathrm{Cu}$ to higher extents than $\mathrm{Fe}$ and $\mathrm{Mn}$. Therefore, determination of heavy metal concentrations in the fruiting bodies of oyster mushrooms is essential in dietary intake studies, because mushrooms constitute important parts of the diet. In this regards, the two mushroom species considered in this study and available in the local markets in Ethiopia, could be recommended for consumption from the point of view of accumulation of the heavy metals analyzed.

The elemental concentrations of the mushrooms in the present study are approximately of similar to those reported in the literature. It should also be noted that some discrepancy is possible due to the different analytical techniques used in other studies on mushrooms. The uptake of different forms and complexes of elements in mushrooms should, however, be considered in more detail as the impacts on human health may vary depending on the chemical forms of the element ingested. Further investigations on the mechanisms of possible accumulations in various tissues and also the synergistic toxic effects of multiple elements will be the aspects of considerable attentions of the authors.

\section{Abbreviations \\ ANOVA: analysis of variance; AR: amount recovered; AUA: Alemaya University of Agriculture; BCF: Bio concentration factor; CITAC: Co-Operation on international traceability in analytical chemistry; FAO: food and agricultural organization; IDL: instrument detection limit; LOD: Limit of detection; LOQ: limit of quantification; LSD: least significance difference; ND: not detected; PDA: Potato dextrose agar; PF: pleurotus florida; PO: pleurotus ostreatus; RDA: recommended dietary allowance; RDI: recommended dietary intake; RSD: Relative standard deviation; SD: Standard deviation; UL: tolerable upper intake levels; WHO: World Health Organization.}

\section{Competing interests}

The authors declare that they have no competing interests.

Authors' contributions

MG contributed to the sampling and analysis. MG, NM and AMT contributed to the design of the study. MG and NM contributed to the interpretation of data and drafting the manuscript. NM contributed to critical revision of the paper. All authors read and approved the final manuscript.

\section{Author details}

'Department of Industrial Chemistry, School of Biological and Chemical Sciences and Technology, Addis Ababa Science and Technology University, P. O. Box 16417, Addis Ababa, Ethiopia. ${ }^{2}$ Department of Chemistry, College of Natural Sciences, Addis Ababa University, P. O. Box 1176, Addis Ababa, Ethiopia. ${ }^{3}$ Department of Chemistry, College of Natural and Computational Sciences, Haramaya University, P. O. Box 138, Haramaya, Ethiopia.

Received: 5 November 2015 Accepted: 22 February 2016

Published online: 29 February 2016

\section{References}

Agrahar-Murugkar D, Subbuakshmi G. Nutritional value of edible wild mushrooms collected from the Khasi Hills of Meghalaya. Food Chem. 2005;89:599-603.

Akyuz M, Kirbag S. Nutritive value of wild edible and cultured mushrooms. Tur J Bio. 2010;34:97-102. doi:10.3906/biy-0805-17.

Alemaya University of Agriculture. Proceedings of the 13th annual research and extension review meeting, Alemaya University of Agriculture, Alemaya, Ethiopia, 26-28 February 1996. 1996. 
Baslar S, Kula I, Dogan Y, Yildiz D, Ay G. A study of trace element contents in plants growing at Honaz Dagi-Denizli, Turkey. Eko. 2009;18:1-7.

Blanusa M, Kucak A, Varnai VM, Saric MM. Uptake of cadmium, copper, iron, manganese and zinc in mushrooms (Boletaceae) from Croatian forest soil. J AOAC Inter. 2001;84:1964-71.

Demirbas A. Heavy metal bioaccumulation by mushrooms from artificially fortified soils. Food Chem. 2001;74:293-301.

Demirbas A. Metal ion uptake by mushrooms from natural and artificially enriched soils. Food Chem. 2002;78:89-93.

Diez VA, Alvarez A. Compositional and nutritional studies on two wild edible mushrooms from Northwest Spain. Food Chem. 2001;75:417-22.

Dulay RMR, Castro MEGD, Coloma NB, Bernardo AP, Cruz AGD, Tiniola RC, Kalaw SP, Reyes RG. Effects and myco-accumulation of lead (Pb) in five pleurotus mushrooms. Inter J Bio Phar All Scie. 2015;4(3):1664-77.

Elekes CC, Busuioc G, lonita G. The bioaccumulation of some heavy metals in the fruiting body of wild growing mushrooms. Not Bot Hort Agrobot Cluj-Napo. 2010a;38(2):147-51.

Elekes CC, Dumitru M. Trace metals concentrations in some wild grown edible mushrooms from wooded area of Romania. Paper presented at the WSEAS International Conference on Environment, Medicine and Health Sciences, At Penang, Malaysia, 23-25 March 2010. 2010.

Eurachem/Co-Operation on International Traceability in Analytical Chemistry Guide. Traceability in Chemical Measurement, https:/www.eurachem.org/images/ stories/Guides/pdf/EC_Trace_2003.pdf. Accessed 12 March 20152003.

European Commission. Document on pesticide residue analytical methods. http://ec.europa.eu/food/plant/pesticides/guidance_documents/docs/guide_ doc_825-00_rev8_en.pdf. Accessed 09 April 2015. 2010

Garcia-Lafuente A, Moro C, Villares A, Guillamón E, Rostagno MA, D'Arrigo M, Martínez JA. Mushrooms as a source of anti-inflammatory agents. Am J Comm Psychol. 2011;48:125-41.

Gast GH, Jansen E, Bierling J, Haanstra L. Heavy metals in mushroom and their relationship with soil characteristics. Chemo. 1988;60:789-99.

Genccelep H, Uzun Y, Tuncturk Y, Demirel K. Determination of mineral contents of wild-grown edible mushrooms. Food Chem. 2009;113:1033-6.

George PL, Ranatunga TD, Reddy SS, Sharma GC. A comparative analysis of mineral elements in the mycelia and the fruiting bodies of Shiitake mushrooms. Am J Food Tech. 2014;9(7):360-9.

Isiloglu M, Yilmaz F, Merdivan D. Concentrations of trace elements in wild edible mushrooms. Food Chem. 2001;73:169-75.

Ita BN, Ebong GA, Essien JP, Eduok SI. Bioaccumulation potential of heavy metals in edible fungal Sporocarps from the Niger Delta region of Nigeria. Pak J Nutr. 2008;7:93-7.

Kalac P. Trace element contents in European species of wild growing edible mushrooms: A review for the period 2000-2009. Food Chem. 2010;122:2-15.

Kalac P, Svoboda L. A review of trace element concentrations in edible mushrooms. Food Chem. 2000;69:273-81.

Kalac P, Burda J, Staskova I. Concentrations of lead, cadmium, mercury, and copper in mushrooms in the vicinity of a lead smelter. Scie Tot Env. 1991;105:109-19.

Kues U, Liu Y. Fruit body production in basidiomycetes. App Micro Biotech. 2000:54:141-52.

Li T, Wang Y, Zhang J, Zhao Y, Liu H. Trace element content of Boletus tomentipes mushroom collected from Yunnan, China. Food Chem. 2011;127:1828-30.

Manzi P, Aguzzi A, Pizzoferrato L. Nutritional value of mushrooms widely consumed in Italy. Food Chem. 2001;73:321-5.

Miller JN, Miller JC. Statistics and Chemometrics for Analytical Chemistry. England: Pearson Harlow; 2010

Mleczek M, Magdziak Z, Goliński P, Siwulski M, Stuper-Szablewska K. Concentrations of minerals in selected edible mushroom species growing in Poland and their effect on human health. Acta Sci Pol Tech Aliment. 2013;12(2):203-14.

Naresh RM, Udaya BRE, Byragi RT. Assessment of heavy metal threat in agaricus bisporus mushrooms cultivated from water hyacinth weed of Kolleru lake, Andhra pradesh-India. Int J Env Sci. 2012:3(1):28-35.

Obodai M, Ferreira ICFR, Fernandes A, Barros L, Mensah DLN, Dzomeku M, Urben AF, Prempeh J, Takli RK. Evaluation of the chemical and antioxidant properties of wild and cultivated mushrooms of Ghana. Mole. 2014;19:19532-48.

Okwulehie IC, Ogoke JA. Bioactive, nutritional and heavy metal constituents of some edible mushrooms found in Abia State of Nigeria. Int J App Microbio Biotech Res. 2013;1:7-15.
Ouzouni PK, Petridis D, Koller WD, Riganakos KA. Nutritional value and metal content of wild edible mushrooms collected from West Macedonia and Epirus, Greece. Food Chem. 2009;115:1575-80.

Quarcoo A, Adotey G. Determination of heavy metals in Pleurotus ostreatus (Oyster mushroom) and Termitomyces clypeatus (Termite mushroom) sold on selected markets in Accra, Ghana. Mycosph. 2013;4(5):960-7.

Racz L, Oldal V. Investigation of uptake processes in a soil/mushroom system by AES and AAS methods. Microchem J. 2000;67(1-3):115-8.

Radulescu C, Stihi C, Busuioc G, Popescu IV, Gheboianu Al, Cimpoca VG. Evaluation of essential elements and heavy metal levels in fruiting bodies of wild mushrooms and their substrate by EDXRF spectrometry and FAA spectrometry. Rom Biotech Lett. 2010;15(4):5444-56.

Ragunathan R, Swaminathan K. Nutritional status of Pleurotus spp. grown on various agro-wastes. Food Chem. 2003;80:371-5.

Ross AC, Taylor CL, Yaktine AL, Del Valle HB, Committee to Review Dietary Reference Intakes for Vitamin D and Calcium; Food and Nutrition Board; Institute of Medicine. Dietary Reference Intakes for Calcium and Vitamin D. Washington D.C: National Academy Press; 2011.

Sara M. Effect of spawn substrates and their inoculation rates on the yield and quality of oyster mushroom (Pleurotus florida). M.Sc. Thesis, Haramaya University. 2007.

Sarikurkcu C, Copur M, Yildiz D, Akata I. Metal concentration of wild edible mushrooms in Soguksu National Park in Turkey. Food Chem. 2011;128:731-4.

Schillaci D, Arizza V, Gargano ML, Venturella G. antibacterial activity of mediterranean oyster mushrooms, species of genus pleurotus (higher basidiomycetes). Int J Med Mushroom. 2013;15:591-4.

Sen I, Alli H, Col B, Celikkollu M, Balci A. Trace metal contents of some wildgrowing mushrooms in Bigadiç (Ballkesir), Turkey. Turk J Bot. 2012;36:519-28.

Sesli E, Tuzen M, Soylak M. Evaluation of trace metal contents of some wild edible mushrooms from Black Sea region, Turkey. J Haz Mat. 2008;160:462-7.

Shukla CS, Biswas MK. Evaluation of different techniques for oyster mushroom cultivation. J Myco Pla Patho. 2000;30:431-5.

Silvestre MD, Lagarda MJ, Farra R, Martineze-Costa C, Brines J. Copper, iron and zinc determination in human milk using FAAS with microwave digestion. Food Chem. 2000;68:95-9.

Singh RP, Chaube HS. Mushroom production technologies: mushroom research laboratory. Pant University of Agriculture and Technology. India: Pantnagar; 1995.

Smith JF, Margarel E. Investigation on to the cultural requirement of a brown capped Agaricus strain (W4II) isolated from curpressus leaf litter. J Hortic Sci. 1995;70:963-74.

Soylak M, Saracoglu S, Tuzen M, Mendil D. Determination of trace metals in mushroom sample from Kayseri, Turkey. Food Chem. 2005;92:649-52.

Stihi C, Radulescu C, Busuioc G, Popescu IV, Gheboianu A, Ene A. Studies on accumulation of heavy metals from substrate to edible wild mushrooms. Rom J Phy. 2011;56(1-2):257-64.

Svoboda L, Zimmermannova K, Kalac P. Concentrations of mercury, cadmium, lead and copper in fruiting bodies of edible mushrooms in an emission area of a copper smelter and a mercury smelter. Scie Tot Env. 2000;246:61-7.

Tedersoo L, Koljalg U, Hallenberg N, Larsson KH. Fine scale distribution of ectomycorrhizal fungi and roots across substrate layers including coarse woody debris in a mixed forest. New Phyto. 2003;159:153-65.

Tuzen M, Sesli E, Soylak M. Trace element levels of mushroom species from East Black Sea region of Turkey. Food Cont. 2007;18:806-10.

Udochukwu U, Nekpen BO, Udinyiwe OC, Omeje FI. Bioaccumulation of Heavy metals and pollutants by edible mushroom collected from Iselu market Benin-city. Int J Curr Microbiol App Sci. 2014;3(10):52-7.

Unak P, Lambrecht FY, Biber FZ, Darcan S. Iodine measurements by isotope dilution analysis in drinking water in Western Turkey. J Radioanal Nucl Chem. 2007;273:649-51.

Uzun Y, Genccelep H, Kaya A, Akcay ME. The mineral contents of some wild edible mushrooms. Eko. 2011;20(80):6-12. doi:10.5053/ekoloji.2011.802.

World Health Organization. Evaluation of Certain Foods Additives and Contaminants (Tweenty-Six Report of the Joint FAO/WHO Expert Committee on Food Additives). WHO Technical Report series, No. 683 Geneva. http://apps.who.int/iris/ bitstream/10665/41546/1NHO_TRS_683.pdf. Accessed 05 December 2015. 1982.

Yoshida S, Muramatsu Y. Determination of major and trace elements in mushroom, plant and soil samples collected from Japanese forests. Int J Env Ana Chem. 1997;67:49-58.

Zadrazil F, Dube HC. The oyster mushroom. Importance and prospects. Mush Resea. 1992;1(1):25-32.

Zhu F, Qu L, Fan W, Qiao M, Hao H, Wang X. Assessment of heavy metals in some wild edible mushrooms collected from Yunnan Province, China. Env Mon Asse. 2011;179:191-9. 